\title{
ON A COLLECTION OF FISHES FROM THE PHILIPPINE ISLANDS, MADE BY MAJ. EDGAR A. MEARNS, SURGEON, U. S. ARMY, WITH DESCRIPTIONS OF SEVEN NEW SPECIES.
}

By Alvin Seale and Barton A. Bean.

In the months of January and February, 1907, two lots of fishes were received from Maj. Edgar A. Mearns, U. S. Army, stationed in the Philippine Islands. One hundred and thirty-two species are represented, including seven which are described as new.

The collections are from Zamboanga, Mindanao, had been well preserved in formalin (here transferred to alcohol), and form part of Accessions Nos. 46983 and 46985, U.S.N.M. By reason of the new species and rare forms contained they are a very acceptable addition to the collection of fishes.

The arrangement of the families of fishes used here is similar to that adopted by Doctor Jordan in recent papers on fishes of the same general fauna and, although not wholly concurred in, is used for convenience and with the view of conforming in classification with the numerous papers already published and being printed upon Philippine fishes.

\section{Family CYPRINIDÆ.}

Barbus quinquemaculatus, new species.

Head, 3.33 ; depth, 3 ; eye, 3.75 ; snout, 3.75 ; interorbital, 2.75 in head; D., 11 ; A., 7 ; scales, $5 / 24 / 2$; eight scales in front of dorsal.

Body moderately robust, back from nuchal region to dorsal fin considerably elevated; snout rather pointed; lower lip included. Barbels four, their length greater than diameter of eye. Mouth small, the maxillary ending on anterior line of orbit.

Pharyngeal teeth in three series, 5, 3, 2, mostly hooked. Gill-rakers very small, about 8 on lower arch. Opercle and preopercle entire.

Caudal peduncle rather robust, its depth 1.25 in its length. 
Head naked, body firmly scaled, the lateral line with a slight curve downward anteriorly, running a little below the axis of the body and upward along the middle of the caudal peduncle. Dorsal and anal

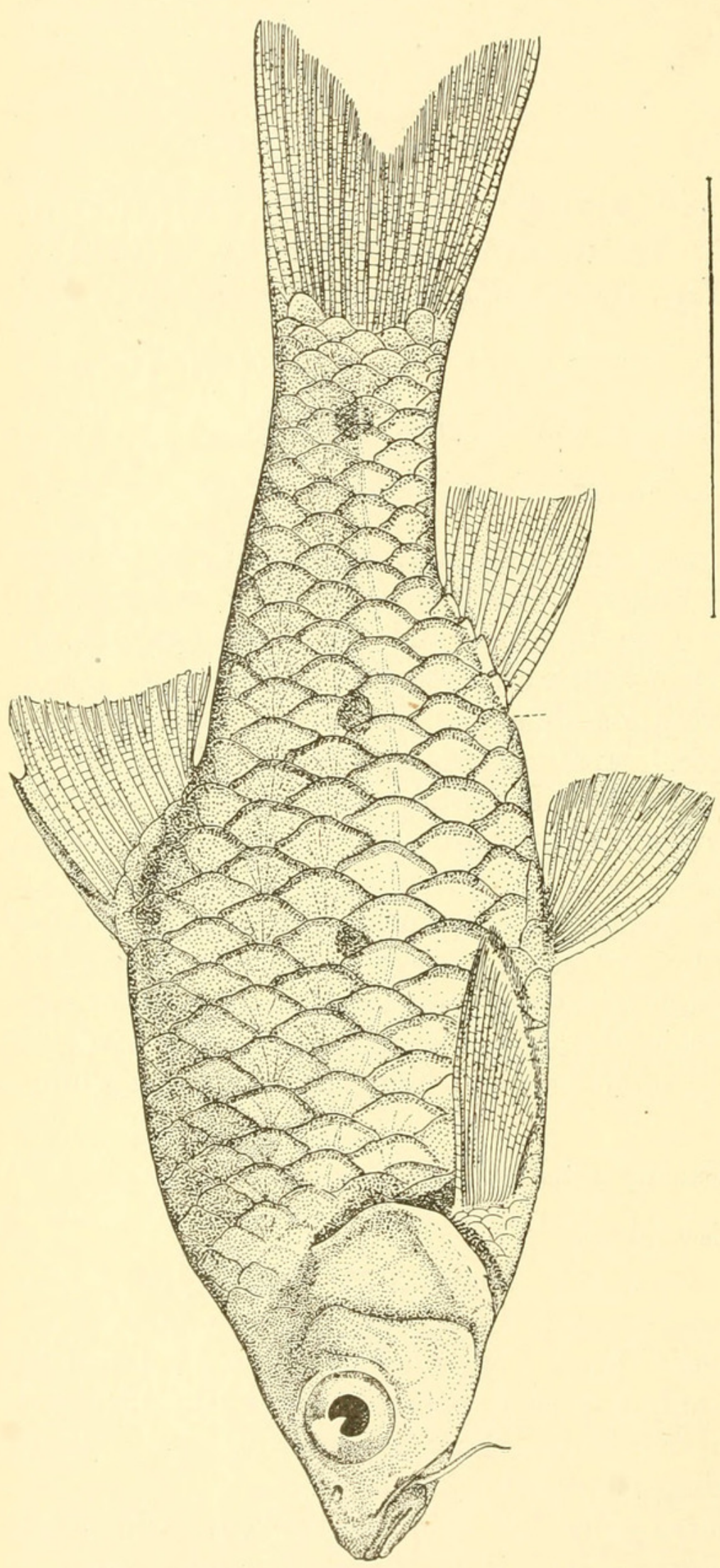

with scaly sheaths. Ventrals with welldeveloped axillary scale.

Second ray of dorsal ossified and strong, its posterior margin slightly denticulate, its length 1.75 in head. Base of dorsal 2 in head. Origin of dorsal midway between the tip of snout and end of caudal vertebræ. Base of anal 2.90 in head; its longest ray 1.75 in head. Caudal large, forked, its longest ray greater than length of head. - Ventrals 1.35 in head; their origin midway bet w e e $n$ origin of pectoral and that of anal, their tips scarcely reaching the anal. Pectorals 1.25 in head.

Color in spirits: Very dark grayish green on upper half of body, yellowish below; scales on lower part of sides with dark margins. A distinct round black spot on base of caudal, another at the origin of the dorsal, a third less distinct at origin of anal, and two round black spots on the median line near the middle of the body. A 
blackish wash at the origin of the lateral line. Dorsal whitish, its osseus ray gray. Caudal and pectorals grayish. Ventrals and anal yellowish.

Type specimen.-Cat. No. 57840, U.S.N.M., 3.50 inches long, from near Zamboanga.

This species shows a wide variation in color; there may be an indistinct dusky line on sides of body, or the various spots may be scarcely perceptible, although present in all our series. The ventral surface may have a wash of bright orange.

Numerous specimens obtained by Doctor Mearns at Mount Malindang all show a splendid purplish reflection with a golden wash to belly.

The spots on these specimens are scarcely perceptible.

This species equals Barbus maculatus var. unnamed. See A. Günther, Voy. H. M. S. Challenger, Report on the Shore Fishes, pp. 53-54.

MEARNSELLA, new genus.

This genus is characterized by the presence of two barbels, and in having the pharyngeal teeth hooked and in two series, inner row with 4 and the outer with 5 teeth; body with the entire abdominal edge trenchant; pectorals elongate and anal of moderate length.

This genus of Cyprinidæ is related to Eustira of Günther, differing chiefly in the presence of barbels, in having but two series of pharyngeal teeth, and a smaller number of dorsal rays.

This genus is named in honor of Major E. A. Mearns, U. S. A., by whom the specimens were collected.

Type.-Mearnsella alestes Seale and Bean.

Mearnsella alestes, new species.

Head, 4; depth, 3.75 ; eye, 3.25 in head, equal to length of snout; interorbital, 2.50 in head; D., 11; A., 15 ; scales, $6 / 32 / 2$.

Body oblong, compressed; thorax and abdomen trenchant; mouth moderately large, oblique, with lower jaw slightly projecting; maxillary ending below anterior margin of eye. A long maxillary barbel on each side, reaching to middle of opercle. Caudal peduncle long and slender, its depth 2 in its length. Pharyngeal teeth small, curved, sharp pointed and hooked, without evident grinding surface. Opercle and preopercle entire.

Lateral line abruptly bent down to axis of pectoral, extending thence along the lower portion of body to caudal. Body covered smooth, deciduous, striated scales.

Dorsal fin located on the posterior half of body, its origin opposite that of anal. Length of dorsal base one-half that of head; its longest 1.10 in head; anal origin midway between base of caudal and lower 
axis of pectoral; base of anal fin 1.35 in head, about equal to its longest ray. Caudal large, forked; its longest ray about equal to head. Ventrals small; 1.75 in

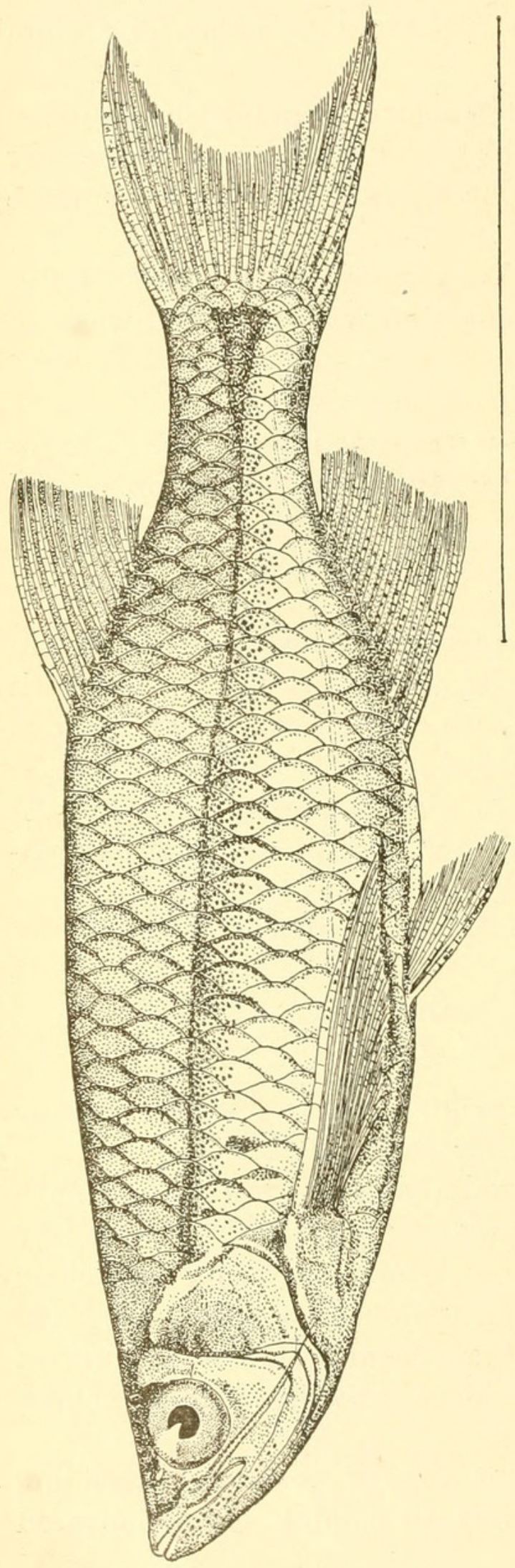
head. Pectorals long, being contained twice in distance of dorsal from tip of snout; their origin considerably below the axis of the body and on a line with the posterior angle of the opercle.

Color in spirits: Dull greenish, lighter below, scales of the sides shaded with brown punctulations. A distinct narrow black line from the opercle to caudal ending in a black blotch at base of caudal fin. Some dusky blotches on sides above pectoral fin. A dusky median line on back; dorsal and caudal with a slight wash of dusky; anal, pectorals, and ventrals, light grayish; a small black spot at the upper axis of the pectoral.

Two specimens.

Type-specimen.-Cat. No. 57841, U.S.N.M.; length, 2.45 inches; cotype, 2 inches long; both from near Zamboanga.

Rasbora punctulatus, new species.

Head, 4; depth, 3.10; eye, 3 in head; snout, 3.50 ; interorbital, 2.50 ; scales, $5 \frac{1}{2} / 26 / 2$; D., 9 ; A., 8 .

No barbels. Mouth moderately small, oblique; the symphysis of the upper jaw notched to receive the curved point of the lower jaw ; maxillary extending to the anterior border of eye. Pharyngeal teeth, curved, pointed, $5,3,2$.

Body oblong, compressed, covered with large, cycloid, striate scales, 10 series in front of dorsal. Lateral line with a low curve 
extending along lower part of sides to caudal. Caudal peduncle robust, its depth two in length.

The dorsal fin without enlarged osseus rays; its longest ray 1.25 in head. The origin of the fin is midway between tip of snout and end of caudal vertebræ. Origin of anal posterior to base of dorsal being midway between the end of the caudal vertebræ and the axis of the pectoral. Base of anal 1.80 in head; its longest ray 1.35 .

Caudal large, forked, its longest ray about equal to head. Pectorals 1.10 in head. Ventrals large, $1.45 \mathrm{in}$ head, their tip about reaching the vent; their origin midway between vent and posterior axis of pectoral.

Color in spirits: Dull greenish above, lighter below, scales of sides with darker margins. A distinct black stripe from the upper part of opercle to caudal fin.

Dusky blotch on opercle; entire base of anal dusky, somewhat dusky at base of caudal, otherwise fins dusky white.

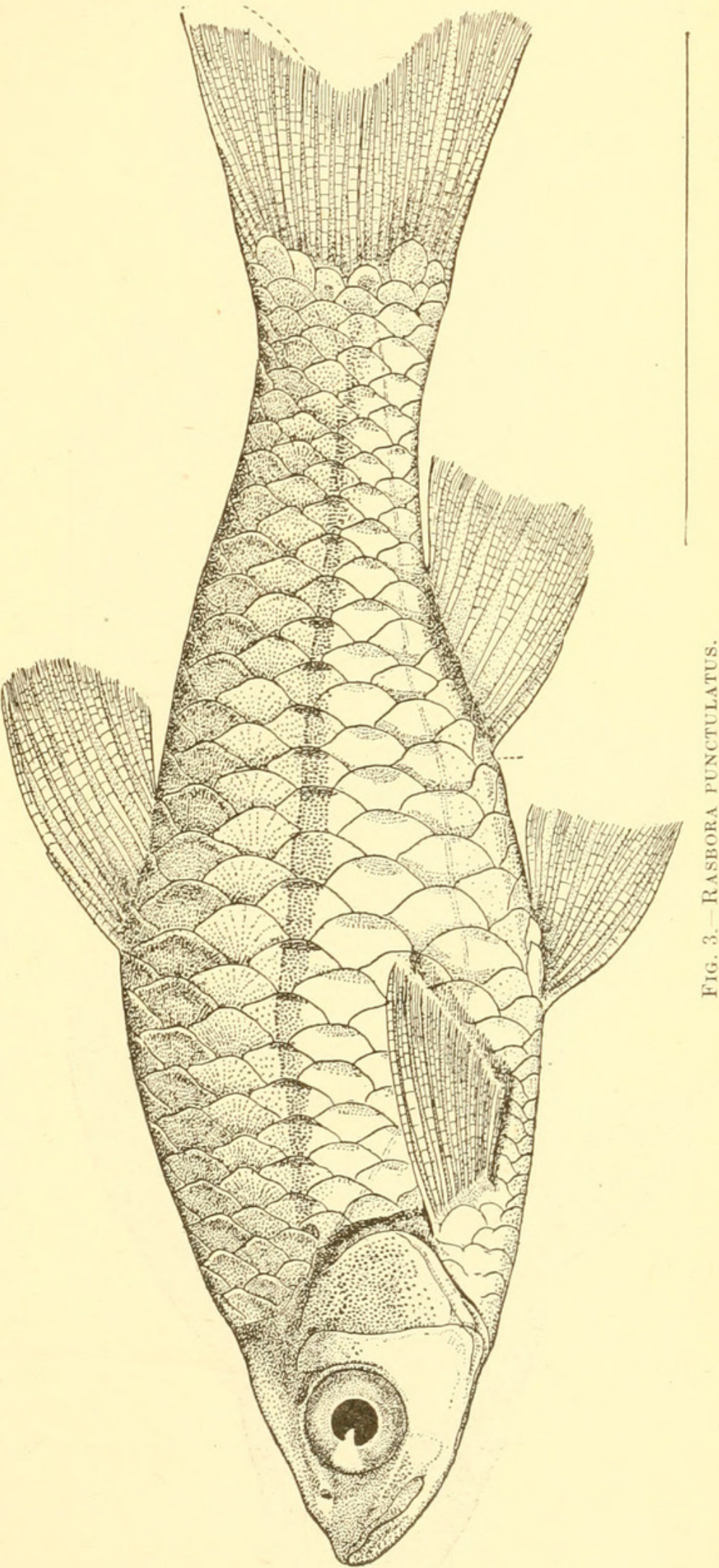

Eleven specimens measuring from 1.50 to 3 inches.

Type-specimen.-Cat. No. 57842, U.S.N.M., 3 inches long, Zamboanga. 


\section{Family POLYNEMIDÆ.}

Polydactylus opercularis, new species.

Head, 3.25; depth, 3.50; eye, 4 in head; snout less than eye, 4.10

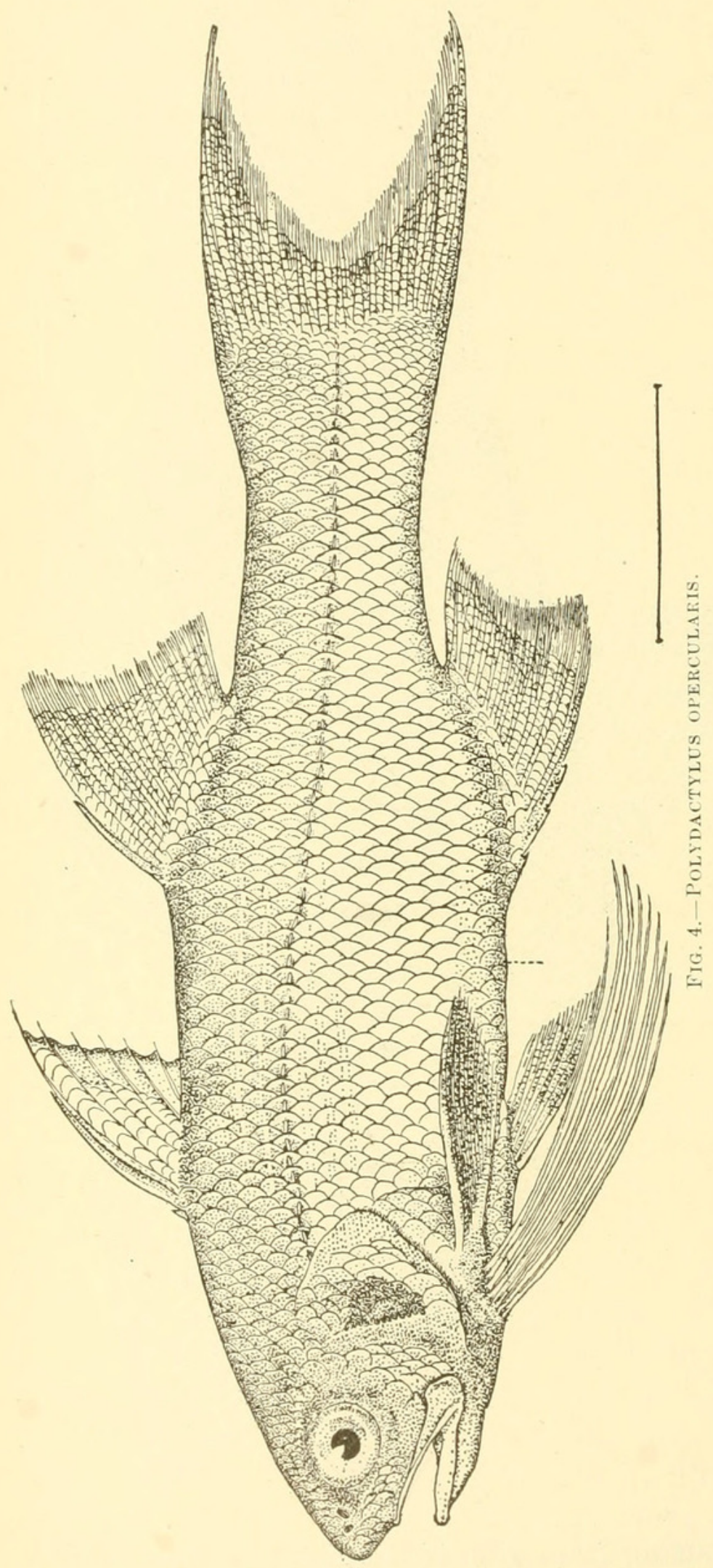

in head; interorbital space equal to eye; D., VIII, 1, 12; A., III, 11 ; P., VIII, + ; scales, $5 / 55 / 8$.

Body oblong; compressed; snout projecting beyond the inferior mouth; maxillary two in head; teeth villiform in jaws and on vomer and palatines; preopercle distinctly serrated; opercle entire; head scaled; adipose eyelid well developed. Gill-rakers long and slender, about 25 on thelower arch. Depth of caudal peduncle contained $1 \frac{1}{2}$ times in its length. Fins all scaled.

Second dorsal spine 1.25 in length of head; longest dorsal ray $1 \frac{1}{2}$ in head; its base 1.25 in its height. Third anal spine much the longest ; longest anal ray contained 1.60 in length of head, equal to length of anal base. Origin of anal fin midway between end of caudal vertebræ and distal end of maxillary. Pectoral fin 1.12 in head. Ventrals 1.75 in head, their tip reaching to anus. Caudal deeply forked; its longest ray equals the longest pectoral filament, the latter as shown in illustration is too long.

Color in spirits silvery white, without dark stripes. A slight bluish tint on upper half of body; dusky blotch on opercles; 
dorsals, caudal, and anal with dusky margins, very wide and distinct on anal. Pectorals and ventrals blackish.

One fine specimen, 6.75 inches long, from Zamboanga.

Type-specimen.-Cat.

No. 57844, U.S.N.M.

Family SERRANID Æ.

Cephalopholis maculatus, new species.

Head, 2.55; depth, 3.10 ; eye, 5 in head; snout, 4; interorbital, 7.25 ; D., IX, 15; A., III, 9 ; scales, 18/95/24; 50 pores in lateral line.

Body oblong, compressed, covered with fine ctenoid scales. Head, including end of maxillary, fully scaled. Mouth large, the premaxillary extending to a line from the posterior margin of the pupil; its distal end equal to the interorbital space. Teeth in jaws, vomer, and palatines; those of jaws in several series; the lower jaw with the inner series enlarged and depressible; the upper jaw with the outer series enlarged and firm; two curved anterior canines in each jaw. Gill-rakers rather short, the longest about equal to width of pupil; 15 rakers on lower arch.

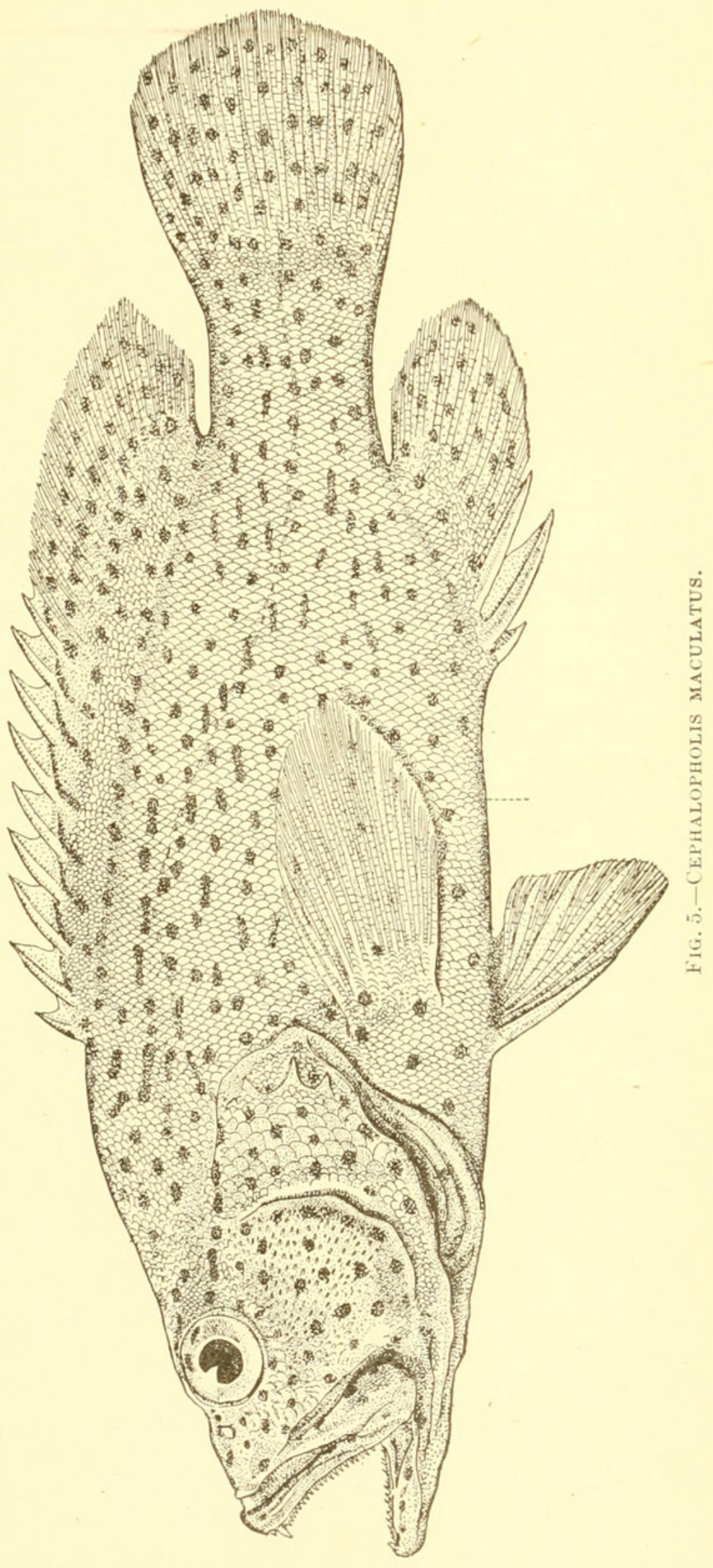

Preopercle rounded, scarcely denticulate. Opercle with three spines, the middle one the largest and nearer to the lower spine than to upper. Opercular flap obtusely pointed, its upper margin being 
almost straight. Caudal peduncle of moderate strength, its depth being equal to its length. Origin of the dorsal fin directly above the axis of the pectorals; the sixth dorsal spine longest, its length 3.25 in head.

First dorsal spine short, its length equal to width of interorbital; the longest dorsal ray is 2.65 in head; base of anal fin 2.35 in head; its second spine being longest and strongest, 3.10 in head; third spine almost its equal in length. Caudal strongly rounded, its median ray 1.75 in head. Pectorals 1.45 in head; ventrals 1.90 in head; their tip barely reaching vent. Origin of ventral is midway between tip of snout and sixth anal ray. Longest anal ray 2.10 in head.

Color in spirits: Entire body and fins golden yellow, covered with numerous round and oblong spots of deep brown (dark), these tending to form irregular longitudinal lines on the upper part of head and jbody; maxillary and mandible with dark spots; pectorals uniform yellowish with two or three spots on base; ventrals yellowish, the outer ray with narrow margin of brown.

Dorsal, anal, and caudal spotted, membranes of spinous dorsal with oblique lines formed by the dark spots.

Two fine specimens, 9.75 inches long, from Zamboanga.

Type-specimen.-Cat. No. 57843, U.S.N.M.

\section{Family SCARICHTHYIDA.}

\section{Chœrops zamboangæ, new species.}

Head, 3 ; depth, 2.75; eye, 5.20 in head; snout, 2.25; interorbital, 3.45; D., XII, 8; A., III, 10 ; scales, $4 \frac{1}{2}, 29,10 ; 7$ in front of D.

Body oblong, compressed; anterior profile of head rounded, lips of moderate thickness; five or six imperfect rows of imbricate scales on cheeks; opercle and preopercle entire; opercles well scaled, top of head and snout naked; maxillary slipping under preorbital, its distal end scarcely reaching to line with anterior margin of orbit; each jaw with four enlarged anterior canines, the second pair of upper jaw much smaller than the first; posterior canine present; no teeth on vomer or palatines; gill-rakers short, their length less than width of pupil, 11 on lower arch; caudal peduncle strong, its depth equal to its length (last anal ray to end of vertebræ); dorsal fin low, the spines stiff, longest dorsal spine equal to orbit (each with a filament); longest dorsal ray 2.50 in head; base of anal fin 1.50 in head, its third spine the longest, the longest ray 2.45 in head; pectorals 1.30 in head; ventrals 1.60 in head, their tip not reaching anal opening; the origin of the ventral fin is midway between tip of snout and base of third anal ray; caudal truncate, none of its rays produced; its median ray 1.75 in head.

Color in spirits: Yellowish white, the upper anterior two-thirds of body (including head) dull light drab; a conspicuous orange line, 
equal to width of eye, extends from base of caudal to axis of pectoral fin; a short broken brown line at lower margin of orbit; a greenish blue line on lower mandible from angle to angle; a slight blotch of yellow on opercle; spinous dorsal drab; soft dorsal yellowish with narrow margin of drab; caudal yellowish; anal, pectorals, and ventrals uniform yellowish.

Two fine specimens from Z a m boanga, length 8.75 and $10 \mathrm{in.}$

Type-specimen.-Cat. No. 57846, U.S.N.M.

Callyodon latifasciatus, new species.

He a d , 3 ; depth, 3 ; eye , 6.50 in head; snout, 2.50; interorbital 3; D., IX, 10; A., II, 9 ; scales, $2 \frac{1}{2}, 23$, 6 ; three rows of scales on cheeks, the lower row of three scales covering the preopercular limb; six rows of scales in front of dorsal.

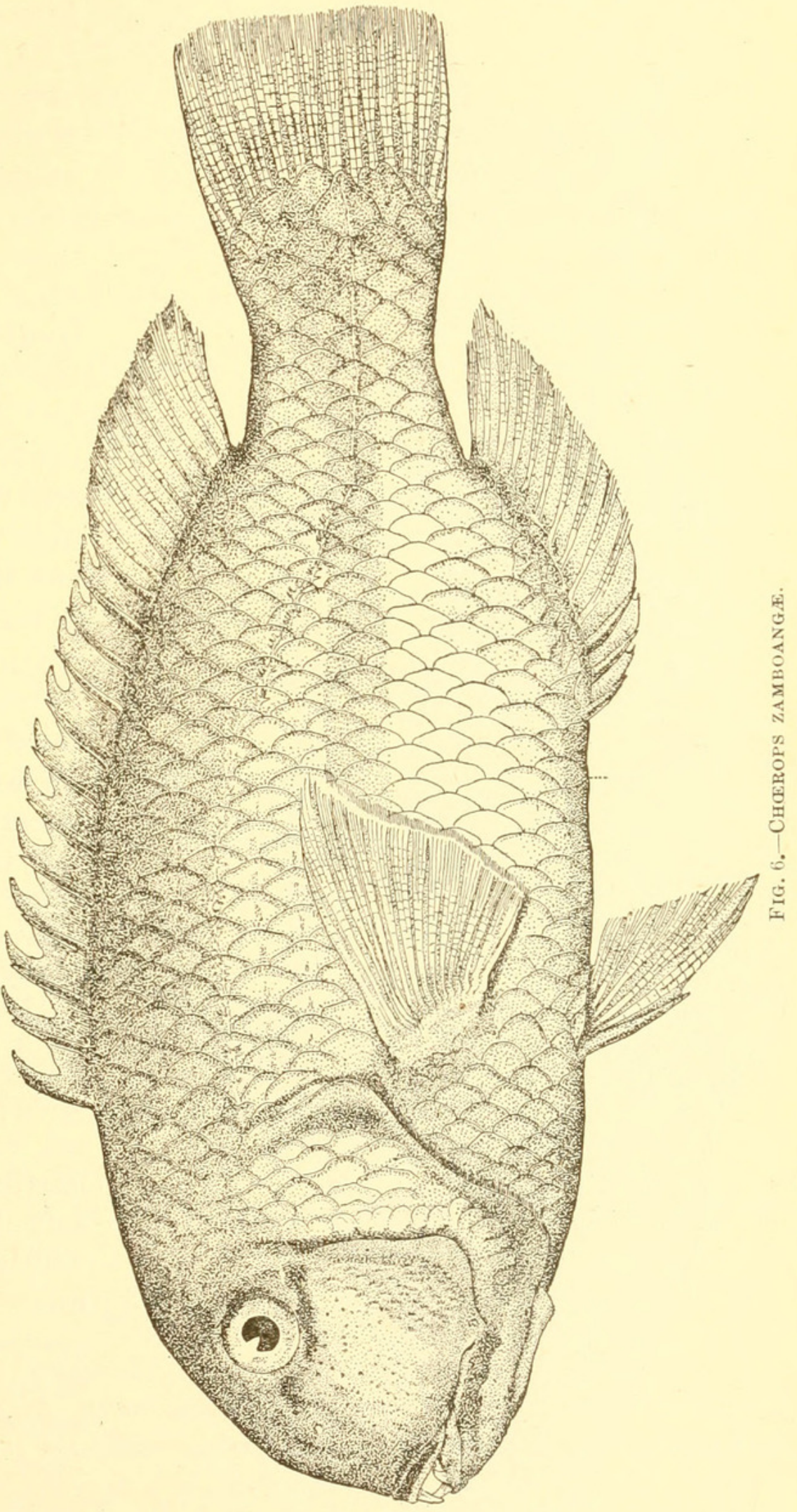

Body oblong, compressed, the upper and lower anterior profile with a low even curve to the tip of the rather pointed snout; lips thin and narrow, covering about half of the upper jaw and less than half 
of the lower; teeth whitish; a posterior canine present on upper jaw; gill-rakers small and setiform, about thirty-seven on outer limb of lower arch. Caudal peduncle stout, its depth equal to its length.

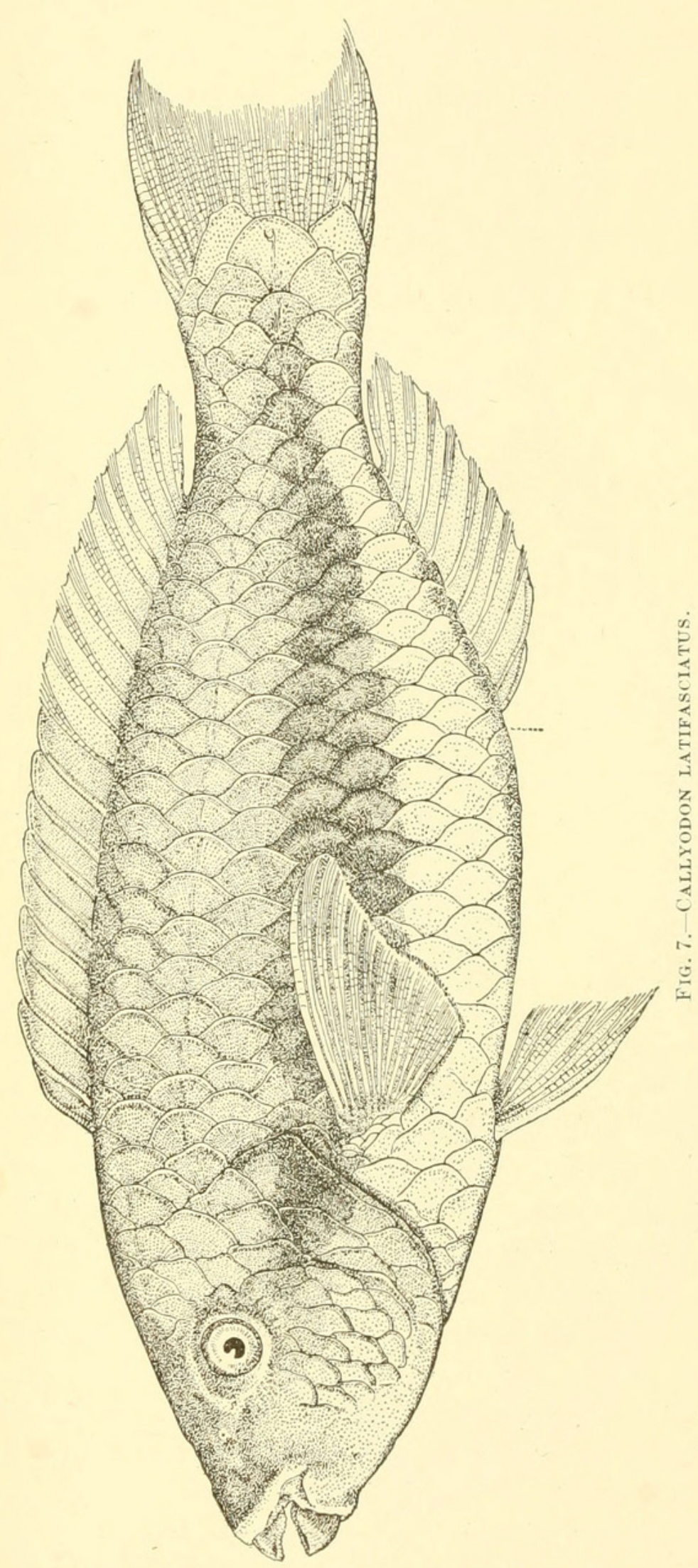

Longest dorsal spine 3.75 in head, longest dorsal ray 2.90 ; base of anal 1.50 in head; its longest ray 3.10 in head; pectorals 1.45 in head; ventrals 1.90 , their tip falling far short of anal opening; the origin of the ventral is midway between tip of snout and third anal ray. Caudal lunate, its middle ray 1.80 and its longest ray 1.30 in head.

Color in spirits: Dull brown above, the lower third of body yellowish white, between the latter and the lateral line there is a wash of deep black extending from the posterior margin of eye to the caudal peduncle. Top of snout dusky; margin of lips yellowish. Spinous dorsal dull greenish with narrow blue margin; soft dorsal fading into whitish, without the blue margin; caudal greenish yellow, with slight dusky margin to upper and lower rays: Anal, ventral, and pectorals, yellowish, without markings; a slight

dusky blotch on upper axis of pectorals.

Two fine specimens, 10.25 and 11.25 inches long from Zamboanga. Type-specimen.-Cat. No. 57845, U.S.N.M.; 11.25 inches long. 
An annotated list of the species other than those described as new, and which Doctor Mearns informs us were all taken at or in the immediate vicinity of Zamboanga, follows:

$$
\text { Family DASYATID无. }
$$

Dasyatis kuhli (Müller and Henle).

One specimen, 9.50 inches long (tail absent).

Tæniura lymma (Forskål).

One specimen. Snout to vent 11 inches; vent to end of caudal 16.50 inches.

Chanos chanos (Forskål).

$$
\text { Family CHANIDA. }
$$

Two specimens, each 12 inches long.

\section{Family CLUPEIDÆ.}

Clupea melanura (Cuvier and Valenciennes).

Five specimens, 4.75 to 5.25 inches long.

Harengula moluccensis Bleeker.

One specimen, 1:75 inches long.

Family DOROSOMATIDÆ.

Konosirus nasus (Bloch).

Four specimens, 5.50 to 6 inches long.

$$
\text { Family ENGRAULIDA. }
$$

Anchovia bœlama (Forskål).

Two specimens, 1.25 and 2.50 inches long. Numerous additional specimens, 3 to 3.50 inches long, are slightly more elongate than figured by Doctor Bleeker, but in other respects agree very well with the description of $A$. bolama.

\section{Family ANGUILLID A.}

Anguilla mauritiana Bennett.

Four specimens, 12 to 22 inches long, bearing collector's numbers 937, 938, 939, and 980 .

\section{Family MURANIDÆ.}

Gymnothorax fimbriata (Bennett).

One fine specimen, 30 inches long, agrees quite well with Doctor Bleeker's figure of Gymnothorax isingleenoides, which Doctor Gunther placed in the synonymy of G. fimbriata.

\section{Family PLOTOSIDÆ.}

Plotosus anguillaris (Bloch).

Three specimens, 8 to 9 inches long, and a very large number of young from 1.75 to 2.50 inches long. 


\section{Family SYNGNATHIDE.}

Gasterotokeus biaculeatus (Bloch).

One specimen, 5 inches long.

Syngnathus schlegelii Kaup.

One specimen.

Corythroichthys bleekeri Day.

Six specimens.

Family HIPPOCAMPIDÆ.

Hippocampus kuda (Bleeker).

Two dried specimens, $3 \frac{1}{2}$ inches long.

Family PEGASIDÆ.

$Z$ alises draconis (Linnæus).

Two specimens, 2.50 inches long.

Family BELONIDÆ.

Tylosurus leiurus (Bleeker).

One specimen, 3.50 inches long.

Tylosurus leiuroides (Bleeker).

Four specimens, 3.50 to 7 inches long.

Family EXOCETIDÆ.

Cypsilurus altipinnis (Cuvier and Valenciennes).

One specimen, 6.75 inches long.

Zenarchopterus dispar (Cuvier and Valenciennes).

One specimen, 6 inches long.

Zenarchopterus philippinus Peters.

Six specimens, 2 to 4 inches long.

\section{Family ATHERINIDÆ.}

Atherina lacunosa Forster.

Numerous specimens, 1.75 to 3.50 inches long. Four examples have a very distinct lateral band, but no dusky shades in pectorals.

$$
\text { Family MUGILIDE. }
$$

Liza waigiensis (Quoy and Gaimard).

Ten specimens, 1.50 to 3.50 inches long.

Liza troscheli (Bleeker).

Numerous specimens, 1 to 3 inches long.

Liza amarula (Cuvier and Valenciennes).

Numerous specimens, 1 to 4.50 inches long. 


\section{Family SPHYRENIDA.}

Sphyræna obtusata (Cuvier and Valenciennes).

Two specimens, 10.75 and 18.25 inches long.

Polydactylus plebeius (Broussonet).

Head, 3 ; depth, 3.75 ; eye, 4.20 in head; snout, 4.75 .

D., VIII, 1, 13; A., III, 13; scales 58 to end of caudal vertebræ, 63 to end of lateral line. Pectoral appendages 5. Color in spirits Yellowish white, darker above, and with a streak along each row of scales;•fins dusky; caudal yellowish, margined with dusky.

Two fine specimens, 9.50 and 10 inches long.

Careful comparison of these examples with specimens from Samoa leave no doubt in our minds that the fish are identical, and that the species described as Polydactylus zophomus by Jordan and McGregor is the young $P$. plebeius. The number of rows of scales are the same.

\section{Family HOLOCENTRIDA.}

Holocentrus cornutus Bleeker.

Three specimens, 8 to 8.50 inches long.

Holocentrus caudimaculatum Rüppell.

One fine specimen, 10.50 inches long, from Zamboanga. Color in spirits yellowish, with indistinct pinkish lines on center of rows of scales. Spinous dorsal orange.

Myripristis murdjan (Forskâl).

One specimen, 8 inches long.

Myripristis mácrolepis (Bleeker).

One specimen, 8 inches long.

\section{Family SCOMBRIDA.}

Scomber macrolepidotus Rüppell.

Two specimens, 10 and 10.50 inches long.

\section{Family CARANGIDA.}

Scombroides toloo-parah (Rüppell).

Two specimens, 6.25 inches long.

Scombroides tala (Cuvier and Valenciennes).

One specimen, 26 inches long.

Caranx speciosus (Forskå1).

One specimen, 15.50 inches long. Cross bands of body alternating wide and narrow; distinct.

Caranx sexfasciatus Quoy and Gaimard.

Six young specimens, 2 to 3.75 i ches long.

Proc. N. M. vol. xxxiii- $07-16$ 
Caranx carangus (Bloch).

Six young specimens, 2.75 to 4.75 inches long.

Megalaspis cordyla (Linnæus).

Four specimens, 8 to 9 inches long.

Alectis ciliaris (Bloch).

One specimen, 13 inches long.

$$
\text { Family EQUULIDA. }
$$

Leiognathus dussumieri (Cuvier and Valenciennes).

One specimen, 2 inches long.

Leiognathus edentula (Bloch).

Two fine specimens, 7 to 7.50 inches long.

\section{Family APOGONICHTHYIDA.}

Arrhamia lineolata (Ehrenberg).

Five young specimens, 1.25 inches long. These have the caudal spot well developed, but do not show a distinct shoulder spot.

Amia orbicularis (Kuhl and v. Hasselt).

One specimen, mutilated, about 3.50 inches long.

Amia fasciata (Quoy and Gaimard).

$\mathrm{O}$-e specimen, 1.50 inches long.

\section{Family AMBASSIDE.}

Priopis lungi Jordan and Seale.

Numerous specimens, 1.20 to 3 inches long.

Priopis urotænia (Bleeker).

Numerous specimens, 1 to 3 inches long.

$$
\text { Family KUHLIIDÆ. }
$$

Kuhlia rupestris (Lacépède).

Two specimens, 5.25 to 11 inches long.

Kuhlia malo (Cuvier and Valenciennes).

One specimen, 2.62 inches long.

\section{Family SERRANIDA.}

Epinephelus merra Bloch.

Two specimens, 6.30 and 8.50 inches long.

Epinephelus tauvina (Forskâl).

Two specimens, 7.75 and 8.50 inches long.

Epinephelus fasciatus (Forskål).

Two specimens, 10.10 and 10.25 inches long.

Epinephelus undulosus (Quoy and Gaimard).

One specimen, 11.25 inches long. 
Cephalopholis urodelus (Forster).

One specimen, 8 inches long.

Cephalopholis obtusauris Evermann and Seale.

One specimen, 12.50 inches long.

Cephalopholis sonnerati (Cuvier and Valenciennes).

Third anal spine slightly longer than the second, 3.50 in head; second anal spine 4.10 in head. One specimen, 14 inches long.

\section{Family LUTIANIDE.}

Lutianus marginatus (Cuvier and Valenciennes).

Seven specimens, 1.50 to 4 inches long.

Lutianus monostigma (Cuvier and Valenciennes).

Five specimens, 2.50 to 4 inches long.

Lutianus fulviflamma (Bleeker).

Six specimens, 2 to 7 inches long.

Lutianus chrysotænia (Bleeker).

Two specimens, 10.50 inches long.

Lutianus gibbus (Forskål).

One specimen, 19 inches long.

Lutianus vitta (Quoy and Gaimard).

One specimen, 10 inches long.

Lutianus rivulatus (Cuvier and Valenciennes).

One specimen, 14 inches long. Four young specimens from the Philippine Islands show less of the rivulated markings of the head, but the dusky vertical cross bands are very distinct.

Lutianus kasmira (Forskâl).

One specimen, 8 inches long.

Diacope sebæ Cuvier and Valenciennes.

Two fine specimens, 8 to 12 inches long.

Gymnocranius lethrinoides (Bleeker).

One specimen, 12.50 inches long.

\section{Family HÆMULIDA.}

Cæsio lunaris (Ehrenberg).

One specimen, 12 inches long.

Cæsio erythrogaster (Kubl and van Hasselt).

Odontonectes Günther, Fishes Brit. Mus., I, p. 265.

One specimen 12 inches long.

Terapon jarbua (Forskal).

Nine specimens, 0.75 to 8.50 inches long.

Terapon theraps Cuvier and Valenciennes.

One very young specimen. 
Scolopsis cancellatus (Cuvier and Valenciennes).

Seven specimens, 7.50 inches long.

Scolopsis bimaculatus Rüppell.

One specimen, 11.50 inches long.

Pristipoma hasta (Bloch).

Three specimens, 1.50 to 13.50 inches long. These represent the form called Pristipoma hasta by Bleeker and figured. ${ }^{a}$

Euelatichthys crassispinus (Rüppell).

One specimen, 4.50 inches long.

Pentapus nemurus (Bleeker).

Two specimens, 11 and 11.50 inches long.

Plectorhynchus hæmatochir (Bleeker).

One specimfen, 16.50 inches long. This specimen agrees in every respect with Bleeker's figure.

\section{Family SPARIDA.}

Lethrinus miniatus (Forster).

Two specimens, 9.25 and 11 inches long.

Lethrinus harak (Forskål).

Three specimens, 2.75 to 12 inches long.

Lethrinus richardsoni Günther.

Three specimens, 8, 10, and 11 inches long.

Lethrinus mashenoides Ehrenberg.

Two specimens, 12.50 and 14.75 inches long. We refer this to his species with some doubt. They have a dusky mark on the sides between base of pectoral and lateral line. Head 3.10 to base of caudal vertebræ, depth 2.60 ; eye 3.75 in head, 1.90 in snout; dorsal $\mathrm{X}, 9$; anal 8; scales 48; teeth, distinct molars on sides of jaws; canines in front; color in spirits silvery, no dark bands or bars except a dusky spot above axil of pectorals.

Lethrinus xanthotænia Bleeker.

One specimen 12 inches long.

\section{Family GERRIDÆ.}

Xystæma kapas (Bleeker).

Three specimens, 2.50 inches long.

Xystæma punctatum (Cuvier and Valenciennes).

Twenty-three young, length .25 to 1.50 inches. Characterized by the seven dark vertical bands.

Xyxtæma oyena (Forskål).

Five specimens, 1 to 4 inches long. 


\section{Family SCIAENIDA.}

Umbrina dussumieri Cuvier and Valenciennes.

Three specimens, 5 inches long.

$$
\text { Family SILLAGINIDÆ. }
$$

Sillago maculato Quoy and Gaimard.

One specimen, 5.50 inches long.

$$
\text { Family MULLID E. }
$$

Pseudupeneus moana Jordan and Seale.

Three specimens, 8.25 to 9 inches long.

Upeneus vittatus (Forskál).

Four specimens, 4.50 to 8.50 inches long.

Family TOXOTIDE.

Toxotes jaculatrix (Pallas).

Two specimens, 7.25 inches long.

\section{Family POMACENTRIDA.}

Abudefduf septemfasciatus (Cuvier and Valenciennes).

Four specimens, 2.10 to 6 inches long.

Abudefduf antjerius (Kuhl and van Hasselt).

One very young specimen, 1 inch long.

$$
\text { Famịly LABRIDÆ. }
$$

Lepidaplois bilunulatus (Lacépède).

Two specimens, 8.75 and 9 inches long.

Color in spirits, pinkish white; a large jet-black blotch extending forward at the posterior axis of soft dorsal; a wide black line extending back from angle of mouth to lower posterior edge of opercle; a black spot on anterior part of spinous dorsal.

Cheilinus trilobatus Lacépède.

One specimen, 7.50 inches long.

Cheilinus chlorurus (Bloch).

One specimen 7 inches long.

Cheilio inermis (Forskål).

Four specimens 10.50 to 11.50 inches long.

$$
\text { Family SCARICHTHYIDÆ. }
$$

Chœrops macrodon Bleeker.

Two specimens 7 and 10 inches long; collected August, 1906.

Scarichthys cæruleopunctatus (Rüppell).

Three specimens 9.50 to 10 inches long.

Scarichthys auritus (Kuhl and van Hasselt).

Two specimens 7.50 and 8 inches long. 


\section{Callyodon nigra Rüppell.}

Two specimens 11 and 12 inches long; collected August, 1906.

Callyodon macrorhinus (Bleeker).

One specimen 14.50 inches long; collected in August, 1906.

Callyodon rivulatus (Cuvier and Valenciennes).

One specimen 13.50 inches long; collected in August, 1906.

Callyodon zonularis Jordan and Seale.

Two specimens 8.50 and 9.50 inches long; collected in August, 1906.

$$
\text { Family PLATACIDA. }
$$

Platax orbicularis (Forskål).

One specimen 12.50 inches long; collected in 1906.

One young specimen 1.875 inches long.

\section{Family SCATOPHAGIDA.}

Scatophagus argus? (Gmelin).

The following description of the young of this species is based on three specimens 0.40 to 0.55 inches long; collected at Zamboanga:

Body strongly compressed, elevated, the outline suborbicular;

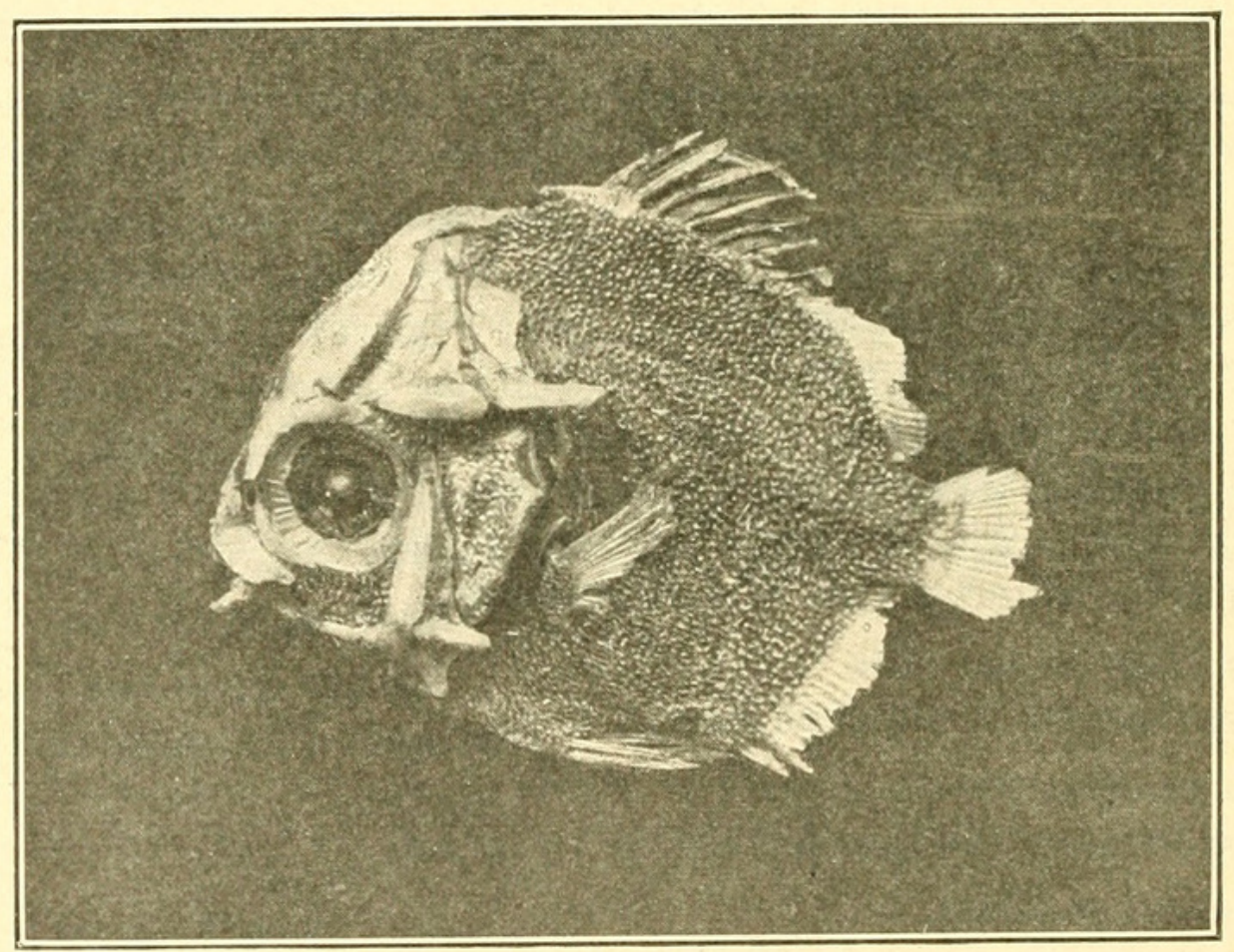

Fig. 8.-Scatophagus ARgus, young.

trunk covered with minute setiform scales; fins unscaled except two or three rows of minute scales at base of soft dorsal and anal; caudal peduncle unarmed; head covered with bony armature; the preorbital unarmed; angle of preopercle spinate; mouth small terminal; teeth consisting of a single series of flat, notched incisors; no teeth on vomer or palatines; branchiostegal rays 5; gills 4; gill membrane slightly attached to isthmus; two dorsal fins; the spinous portion 
with about eleven spines; anal with three spines; ventrals large, thoracic, I, 5.

Head, 2.10 ; depth, 1.25; eye, 2.30 in head; snout, 3 in head: interorbital about equal to eye.

D. - XI, 16; A. III, 14; Br. 5; gills 4, a slit behind fourth. Gillrakers short, about 12 on lower limb. Body without distinct scales, velvety. Lateral line present but indistinct.

Head inclosed in a bony armature. A strong protuberance at the upper posterior margin of the orbit followed by a strong spine. Above this a flat nuchal spine. Preopercle with a strong vertical stay and three spine-like points diverging from its lower angle. Preorbital narrow, unarmed; mouth small. Teth, a single series of compressed lobate incisors about six on each side of lower jaw and twelve in the upper.

Body elevated, compressed. Depth of caudal peduncle about twice its length, without spines or plates. Dorsal fins scarcely united; fourth spine the longest, its length slightly greater than diameter of orbit. Soft dorsal low, its height less than that of spinous dorsal, anal similar to soft dorsal; the three anal spines about equal in length. Caudal rounded, its length 1.50 in head. Pectorals broad with about 15 united rays. Ventrals large, I, 5; their length 1.75 in head, their tip almost reaching anal.

Color very dark brown with four indistinct black vertical bands of less width than the interspaces. Spinous dorsal and ventrals black; soft dorsal, anal, and pectorals, yellowish white.

An additional specimen, 1.50 inches long, is included in the lot.

\section{Family ACANTHURIDA.}

Acanthurus tuberosus (Cuvier and Valenciennes).

One 11-inch specimen.

Acanthurus lituratus (Forster).

One 16-inch specimen.

Acanthurus marginatus Cuvier and Valenciennes.

One 12-inch specimen, 1906.

Acanthurus annulatus (Quoy and Gaimard).

One 20-inch specimen.

Hepatus dussummieri (Cuvier and Valenciennes).

One specimen, length 12.75 inches.

Hepatus celebicus (Bleeker).

Six specimens, length 2 to 2.25 inches, and three young.

\section{Family SIGANIDA.}

Siganus virgatus (Cuvier and Valenciennes).

Two specimens, length 8.25 and 9.20 inches.

Siganus fuscescens (Houttuyn).

Two specimens length 7 and 7.50 inches. 
Siganus vermiculatus (Kuhl and van Hasselt).

Two specimens, length 8 and 9.25 inches.

\section{Family BALISTIDE.}

Balistes verrucosus Bleeker.

One specimen.

\section{Family TETRAODONTIDE.}

Canthigaster compressus (Procé).

One specimen, length 2.50 inches.

Tetraodon immaculatus Bloch.

Three specimens.

Tetraodon reticulatus Bloch and Schneider.

One specimen, length 1.50 inches.

Tetraodon patoca Buchanan.

Nine specimens, length 0.50 to 4 inches.

Spheroides lunaris? (Bloch).

One very young, length 0.50 inch.

Family SCORPANIDA.

Synancidium horridum (Linnæus).

Three examples, 9 and 10 inches long.

Family NOTOTHENIIDÆ.

Parapercis cylindrica? (Bloch).

One very young specimen.

Family GOBIIDE.

Mapo fuscus (Rüppel1).

Eleven specimens.

Gnatholepis sternbergi Smith.

One young specimen, length 1 inch, referred with some doubt to this species.

Odontobutis obscurus (Peters) .

Nine speciments.

Drombus plackyi Jordan and Seale.

Two specimens, one, length 2.50 inches, the other length 2.25 inches.

These specimens are larger and better preserved than the type with which we have compared them. The dark blotch in the spinous dorsal is very distinct. There is also a light margin to the soft dorsal and a whitish margin to the upper caudal rays, the body is dusky without marks. The white spot at the upper axis of pectoral is indistinct.

Eleotris ophiocephalus (Kuhl and van Hasselt).

One young, length 1.50 inches. 


\section{$2 \mathrm{BHL}$ Biodiversity Heritage Library}

Seale, Alvin and Bean, Barton A. 1907. "On a collection of fishes from the Philippine Islands, made by Maj. Edgar A. Mearns, surgeon, U.S. Army, with descriptions of seven new species." Proceedings of the United States National Museum 33, 229-248.

View This Item Online: https://www.biodiversitylibrary.org/item/53442

Permalink: https://www.biodiversitylibrary.org/partpdf/51943

\section{Holding Institution}

Smithsonian Libraries

\section{Sponsored by}

Smithsonian

\section{Copyright \& Reuse}

Copyright Status: Public domain. The BHL considers that this work is no longer under copyright protection.

This document was created from content at the Biodiversity Heritage Library, the world's largest open access digital library for biodiversity literature and archives. Visit BHL at https://www.biodiversitylibrary.org. 